\title{
Waarnemingen.be - Plant occurrences in Flanders and the Brussels Capital Region, Belgium
}

\author{
Roosmarijn Steeman', Wouter Vanreusel', Rutger Barendse', Filip Verloove ${ }^{3}$, \\ Nico Wysmantel ${ }^{4}$, Walter Van den Bussche ${ }^{4}$, Thomas Gyselinck ${ }^{4}$, \\ Pieter Hendrickx ${ }^{5}$, Arnout Zwaenepoel ${ }^{6}$, Pierre Van Vooren ${ }^{5}$, Steven Jacobs ${ }^{7}$, \\ Peter Desmet ${ }^{8}$, Karin Gielen', Marc Herremans', Kristijn R.R. Swinnen ${ }^{1,9}$
}

I Natuurpunt Studie, Coxiestraat 11, 2800 Mechelen, Belgium 2 Plantenwerkgroep Genk, 3600 Genk, Belgium 3 Botanic Garden Meise, Bouchout Domain, Nieuwelaan 38, 1860 Meise, Belgium 4 Natuurpunt, Coxiestraat 11, 2800 Mechelen, Belgium 5 Natuurpunt Beheer, Coxiestraat 11, 2800 Mechelen, Belgium 6 WVI, Baron Ruzettelaan 35, 8310 Brugge, Belgium 7 Ecosystem Management Group, Biology Department, University of Antwerp, Campus Drie Eiken, Universiteitsplein 1, 2610 Wilrijk, Belgium 8 Research Institute for Nature and Forest (INBO), Kliniekstraat 25, 1070, Brussels, Belgium 9 Evolutionary Ecology Group, Biology Department, University of Antwerp, Campus Drie Eiken, Universiteitsplein 1, 2610 Wilrijk, Belgium

Corresponding author: Kristijn R.R. Swinnen (kristijn.swinnen@natuurpunt.be)

Academic editor: Y. Mutafchiev | Received 7 July 2017 | Accepted 28 July 2017 | Published 8 August 2017

Citation: Steeman R, Vanreusel W, Barendse R, Verloove F, Wysmantel N, Van den Bussche W, Gyselinck T, Hendrickx P, Zwaenepoel A, Van Vooren P, Jacobs S, Desmet P, Gielen K, Herremans M, Swinnen KRR (2017) Waarnemingen.be Plant occurrences in Flanders and the Brussels Capital Region, Belgium. PhytoKeys 85: 1-10. https://doi.org/10.3897/ phytokeys.85.14925

Resource citation: Steeman R, Vanreusel W, Barendse R, Verloove F, Wysmantel N, Van den Bussche W, Gyselinck T, Hendrickx P, Zwaenepoel A, Van Vooren, P, Desmet P, Gielen K, Herremans M, Swinnen KRR (2016) Waarnemingen.be - Plant occurrences in Flanders and the Brussels Capital Region, Belgium. Dataset/Occurrence: https://doi.org/10.15468/fyuklz

\begin{abstract}
Waarnemingen.be - Plant occurrences in Flanders and the Brussels Capital Region, Belgium is a species occurrence dataset published by Natuurpunt. The dataset contains almost 1.2 million plant occurrences of 1,222 native vascular plant species, mostly recorded by volunteers (citizen scientists), mainly since 2008 . The occurrences are derived from the database http://www.waarnemingen.be, hosted by Stichting
\end{abstract}

Copyright Roosmarijn Steeman et al. This is an open access article distributed under the terms of the Creative Commons Attribution License (CC BY 4.0), which permits unrestricted use, distribution, and reproduction in any medium, provided the original author and source are credited. 
Natuurinformatie and managed by the nature conservation NGO Natuurpunt. Together with the datasets Florabank1 (Van Landuyt and Brosens 2017) and the Belgian IFBL (Instituut voor Floristiek van België en Luxemburg) Flora Checklists (Van Landuyt and Noé 2015), the dataset represents the most complete overview of indigenous plants in Flanders and the Brussels Capital Region.

\section{Keywords}

native, distribution, observation, citizen science, waarnemingen.be

\section{General description}

Purpose: Plants have a long history of being recorded by both amateur and professional botanists. Volunteer data from amateur botanists were always an important source of distribution data of plants. The atlas of Flanders and the Brussels Capital region (Van Landuyt et al. 2006) was based on the teamwork of many volunteer botanists, NGOs, scientific institutes and governmental organisations. Since Natuurpunt, the largest nature conservation NGO in Flanders, Belgium, launched the web portal www.waarnemingen.be in 2008, the number of plant observations in Flanders and the Brussels Capital Region has risen sharply. Beside IFBL-mapping and projectrelated observations, this database is easily used for occasional observations and can be used for monitoring (wildlife) areas. Old notebooks and reports were screened and stored in the database (Steeman et al. 2012). The team of specialized validators motivates the inexperienced observers and validates observations. Here we publish these records on a IFBL (Instituut voor Floristiek van België en Luxemburg) grid cell resolution of $4 \times 4 \mathrm{~km}^{2}$.

\section{Data published through}

Source publication: http://dataset.inbo.be/planten-natuurpunt-occurrences This paper describes version 1.4 of this resource.

Dataset on GBIF: http://www.gbif.org/dataset/bfc6fe18-77c7-4ede-a5559207d60d1d86, DOI: https://doi.org/10.15468/fyuklz

Taxonomic coverage: the taxonomic reference for the dataset is Heukels' Flora of the Netherlands by Van der Meijden (2005) which follows the classification as suggested by the Angiosperm Phylogeny Group (APG II 2003).

General taxonomic coverage description: The datasets contains 1,222 native vascular plant (Plantae) species (as well as an additional number of subspecies, varieties, forms, hybrids and multispecies) recorded in Flanders and the Brussels Capital Region. This includes angiosperms (flowering plants), gymnosperms, ferns and allies, but not algae, mosses and lichens. If the observer remarked that the specific individual of this native plant was introduced by man, then this is recorded in the field establishmentMeans. 


\section{Taxonomic ranks}

Kingdom: Plantae

Families: Adoxaceae, Alismataceae, Amaranthaceae, Amaryllidaceae, Apiaceae, Apocynaceae, Aquifoliaceae, Araceae, Araliaceae, Asparagaceae, Aspleniaceae, Asteraceae, Athyriaceae, Balsaminaceae, Berberidaceae, Betulaceae, Blechnaceae, Boraginaceae, Brassicaceae, Butomaceae, Buxaceae, Campanulaceae, Cannabaceae, Caprifoliaceae, Caryophyllaceae, Celastraceae, Ceratophyllaceae, Cistaceae, Colchicaceae, Convolvulaceae, Cornaceae, Crassulaceae, Cucurbitaceae, Cupressaceae, Cyperaceae, Cystopteridaceae, Dennstaedtiaceae, Dioscoreaceae, Droseraceae, Dryopteridaceae, Elaeagnaceae, Elatinaceae, Equisetaceae, Ericaceae, Euphorbiaceae, Fabaceae, Fagaceae, Gentianaceae, Geraniaceae, Grossulariaceae, Haloragaceae, Hydrocharitaceae, Hypericaceae, Iridaceae, Juncaceae, Juncaginaceae, Lamiaceae, Lentibulariaceae, Liliaceae, Linaceae, Lycopodiaceae, Lythraceae, Malvaceae, Marsileaceae, Melanthiaceae, Menyanthaceae, Molluginaceae, Montiaceae, Myricaceae, Nartheciaceae, Nymphaeaceae, Oleaceae, Onagraceae, Onocleaceae, Ophioglossaceae, Orchidaceae, Orobanchaceae, Osmundaceae, Oxalidaceae, Papaveraceae, Plantaginaceae, Plumbaginaceae, Poaceae, Polygalaceae, Polygonaceae, Polypodiaceae, Potamogetonaceae, Primulaceae, Ranunculaceae, Resedaceae, Rhamnaceae, Rosaceae, Rubiaceae, Ruppiaceae, Salicaceae, Santalaceae, Sapindaceae, Saxifragaceae, Scrophulariaceae, Solanaceae, Taxaceae, Thelypteridaceae, Typhaceae, Ulmaceae, Urticaceae, Verbenaceae, Violaceae, Zosteraceae

The number of records (observations) per plant species is shown in Fig. 1 and the top 10 most frequently recorded species are shown in Table 1.

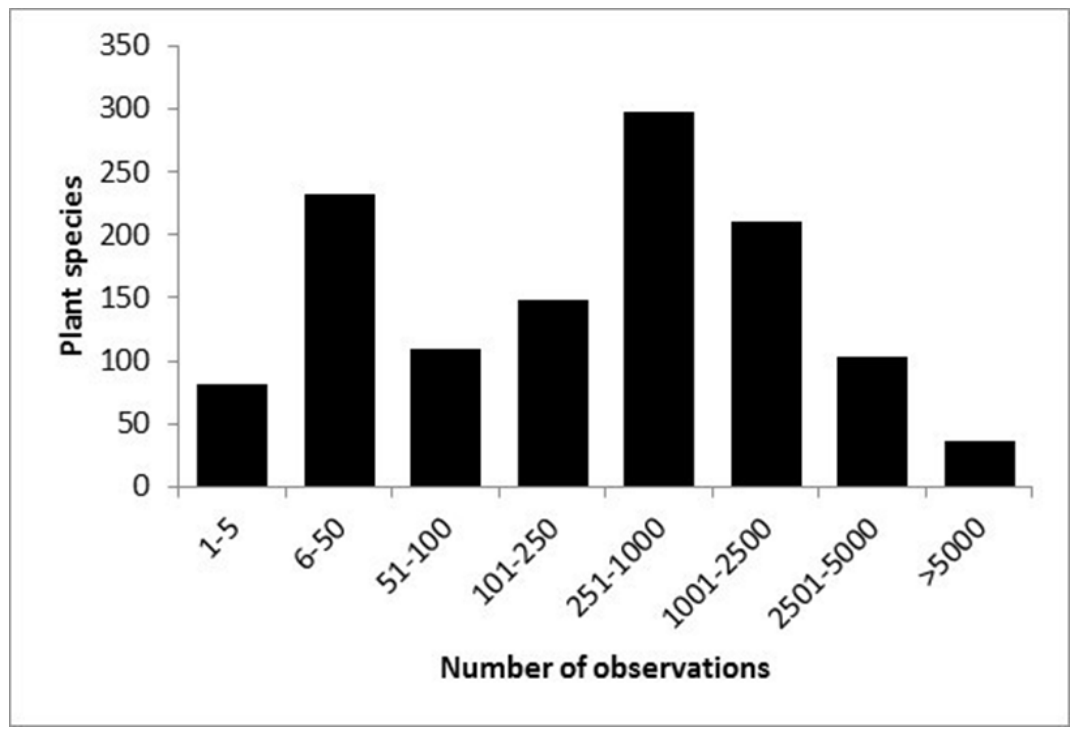

Figure I. The number of observations per plant species (excluding subspecies, varieties, forms, hybrids and multispecies). 
Table I. Top 10 of the most frequently recorded plant species in www.waarnemingen.be.

\begin{tabular}{c|c}
\hline Scientific name & Number of observations \\
\hline Urtica dioica & 8687 \\
\hline Cardamine pratensis & 8446 \\
\hline Glechoma hederacea & 7741 \\
\hline Quercus robur & 7695 \\
\hline Plantago lanceolata & 7438 \\
\hline Filipendula ulmaria & 7024 \\
\hline Cirsium arvense & 7010 \\
\hline Anemone nemorosa & 6902 \\
\hline Ranunculus repens & 6863 \\
\hline Achillea millefolium & 6830 \\
\hline
\end{tabular}

\section{Spatial coverage}

General spatial coverage: Flanders and the Brussels Capital Region (Fig. 2). These regions are situated in the north of Belgium and cover an area of $13,522 \mathrm{~km}^{2}$ and 162 $\mathrm{km}^{2}$ respectively $\left(13,684 \mathrm{~km}^{2}\right.$ in total or $45 \%$ of the Belgian territory).

Flanders is largely covered by agricultural land (51\%), urban areas (30\%) and woodland (10\%) while the Brussels Capital Region mainly consists of urban areas $(73 \%)$, woodland (12\%) and other green areas (10\%) (Vriens et al. 2011). All occurrence data are generalized to IFBL grid cells of $4 \times 4 \mathrm{~km}^{2}$ (Fig. 3), with the grid codes indicated in the field verbatimCoordinates. The WGS84 centroids of these grid cells are calculated in decimalLatitude/Longitude with a coordinateUncertaintyInMeters of 2,828 meters (using Wieczorek et al. 2004).

Coordinates: $50^{\circ} 40^{\prime} 48^{\prime \prime} \mathrm{N}$ and $51^{\circ} 30^{\prime} 36^{\prime \prime} \mathrm{N}$ Latitude; $2^{\circ} 32^{\prime} 24^{\prime \prime} \mathrm{E}$ and $5^{\circ} 55^{\prime} 12^{\prime \prime} \mathrm{E}$ Longitude.
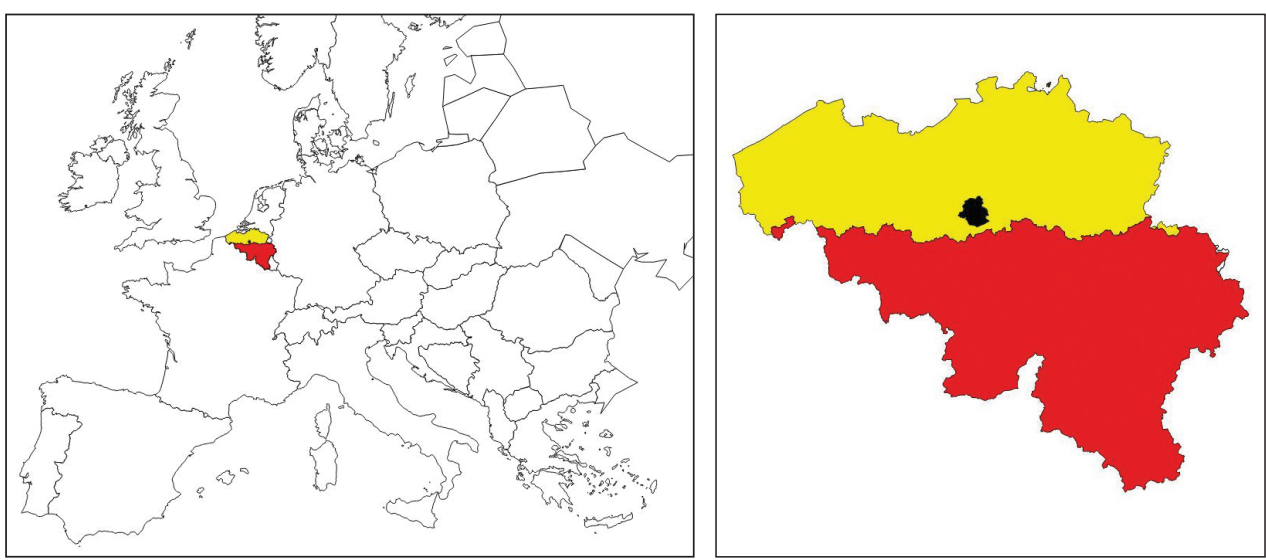

Figure 2. Location of Belgium within Europe (left) and the three administrative regions in Belgium (yellow $=$ Flanders, black $=$ Brussels Capital Region, red $=$ Wallonia $)$ 


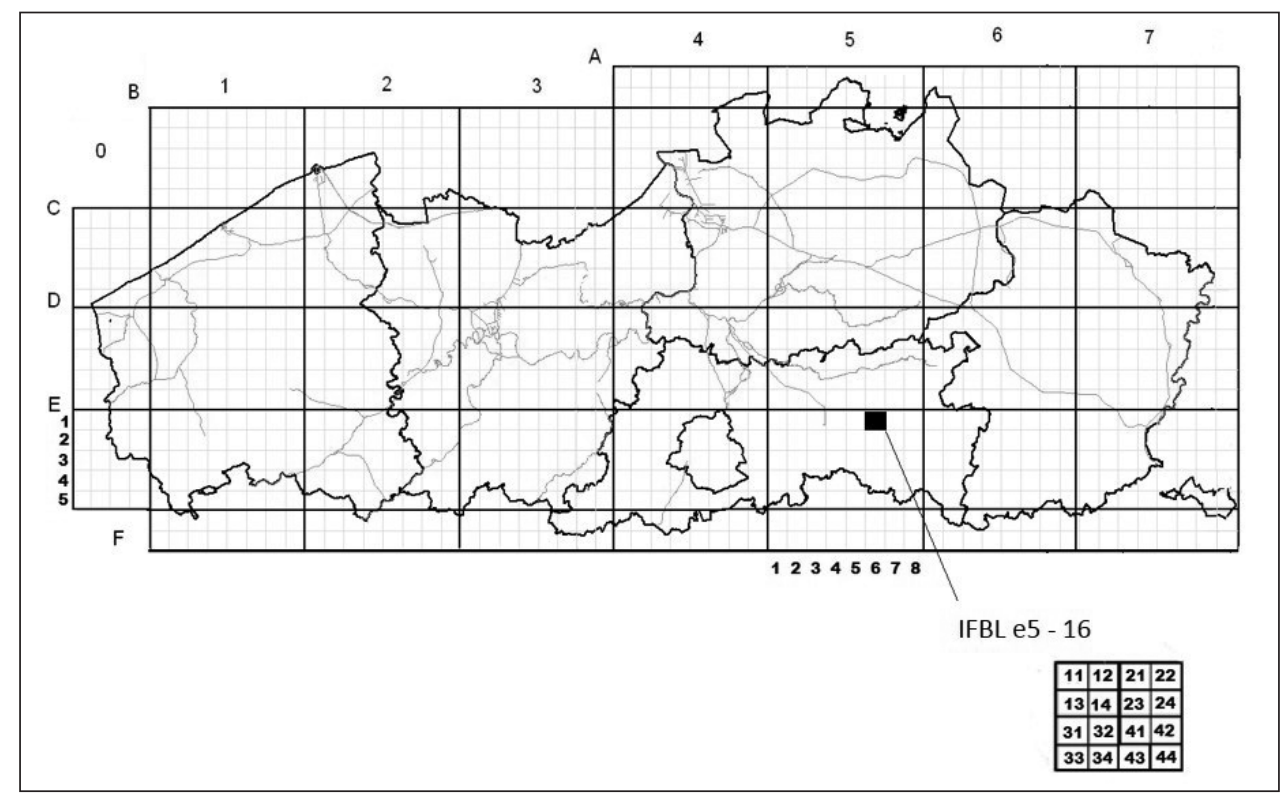

Figure 3. $4 \times 4 \mathrm{~km}^{2}$ IFBL grid cells in Flanders and the Brussels capital region.
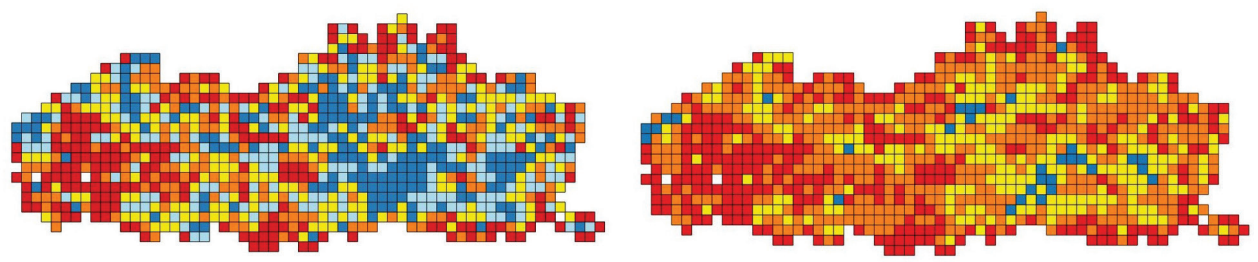

Figure 4. Left: the number of plant observations per IFBL grid cell. Red (1-200), orange (201-500), yellow (501-1000), light blue (1001-2000) and dark blue (2001-14000). Right: the number of plant species (subspecies, varieties, forms, hybrids and multispecies not included) per IFBL grid cell. Red (1-150), orange (151-300), yellow (301-450) and blue (451-600). The two white IFBL grid cells in the west of Flanders are locations without plant observations.

We show the number of plant observations and the number of plant species per IFBL grid cell (Fig. 4). Figure 5 shows the frequency distribution of plant species per number of IFBL grid cells. The top 10 of the most widespread recorded plant species is shown in Table 2.

Temporal coverage: June 30, 1855 - December 31, 2016

The majority of records was collected since the launch of www.waarnemingen.be in 2008 (Fig. 6). 


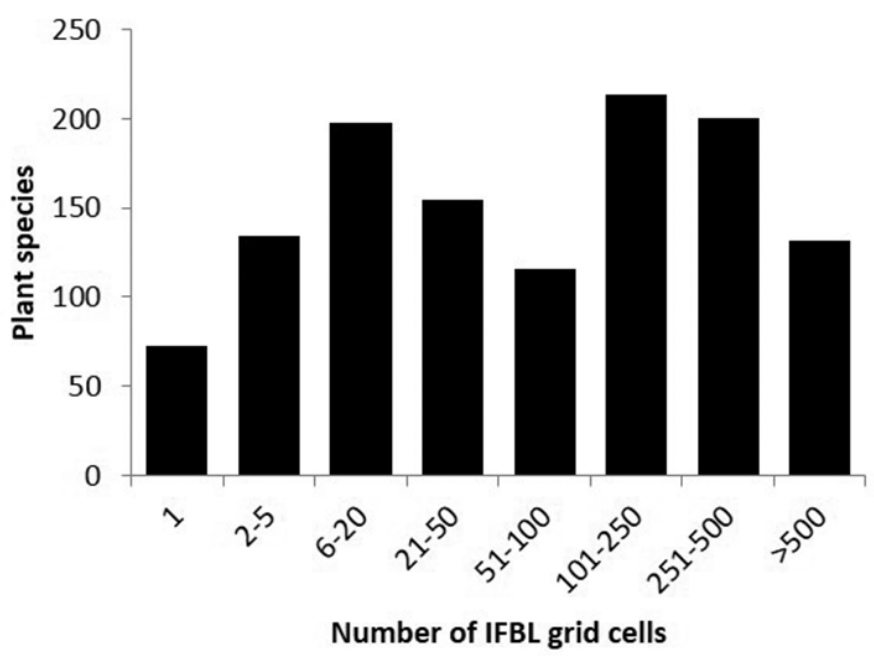

Figure 5. Known distribution based on the data from www.waarnemingen.be of true plant species (subspecies, varieties, forms, hybrids and multispecies not included) based on the number of IFBL grid cells with observation of this species.

Table 2. Top 10 of plant species registered in the most IFBL grid cells.

\begin{tabular}{c|c}
\hline Scientific name & Number of IFBL grid cells \\
\hline Urtica dioica & 790 \\
\hline Achillea millefolium & 777 \\
\hline Plantago lanceolata & 772 \\
\hline Glechoma hederacea & 765 \\
\hline Ranunculus repens & 765 \\
\hline Cardamine pratensis & 762 \\
\hline Cirsium arvense & 743 \\
\hline Sambucus nigra & 740 \\
\hline Tanacetum vulgare & 739 \\
\hline Rumex obtusifolius & 736 \\
\hline
\end{tabular}
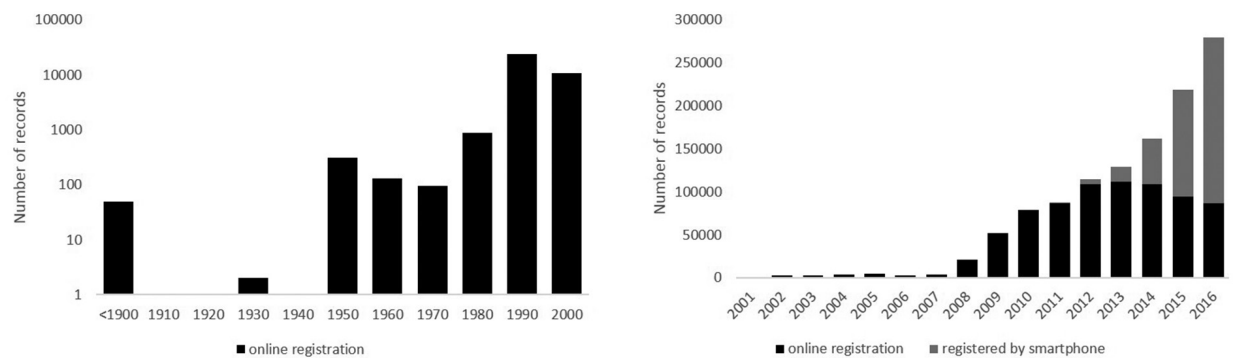

Figure 6. Number of collected records between 1855 and 2000 (left) and between 2001 and 2016 (right). Each number on the left $\mathrm{x}$-axis is a period of 10 year (e.g., $1910=1901-1910$, etc.). Note the difference between the scales on the $y$-axis between the left and right figures and the strong increase in smartphone registration of records since the launch of an app (ObsMapp for Android) in 2012. 

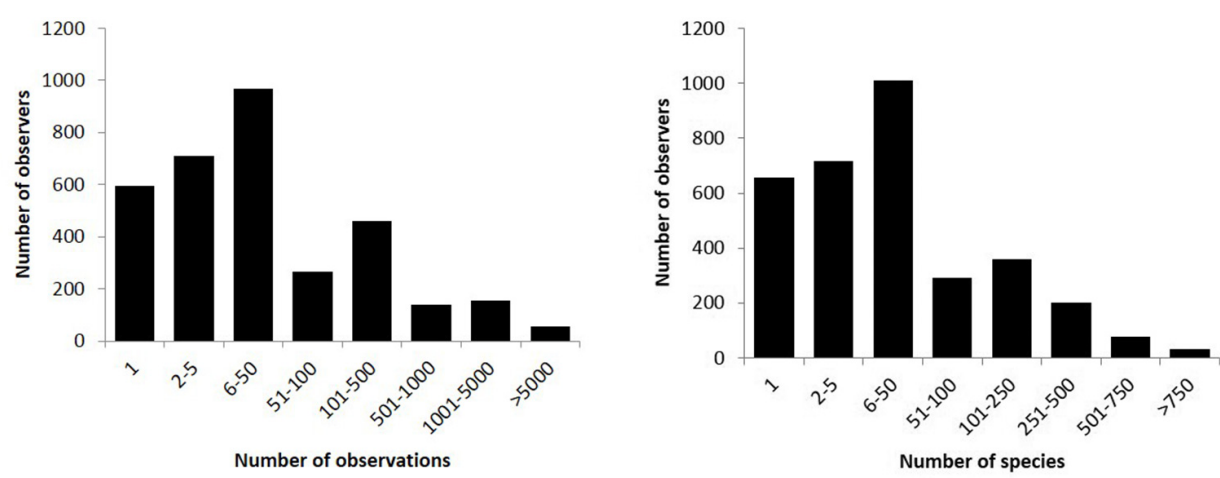

Figure 7. Frequency distribution of observers per number of observations (left) or species (right). Note the difference between the $\mathrm{x}$-axis in the left and right $\mathrm{y}$-axis.

\section{Methods}

Sampling description: Most observations (species, date, location, observer) were recorded by volunteers (citizen scientists). The dataset also includes historical records and datasets imported in waarnemingen.be. The large majority of records (95\%) is a casual observation (presence only record). 5\% of observations were registered as part of a species checklist. This is also recorded in the field samplingProtocol. The frequency distribution of number of observers per number of records or species is shown in Fig. 7.

Quality control description: Recorded data are verified by a group of botanical experts (including professional botanists), based on collected specimens, the observer's species knowledge, added photographs and known species list of locations. The validation procedure from www.waarnemingen.be consists of an interactive procedure in which observers can be asked for additional information by a team of validators, after which the validator manually adds a validation status. Manual validation focuses on rare species, species that are reported outside their known range and observations accompanied by pictures. Records that are not manually validated are additionally checked by an automated validation procedure that takes into account the number of manually validated observations of a species within a specified date and distance range. $12 \%$ of the plant records in this dataset are supported by photographs in www.waarnemingen.be. The validation status is indicated in the field identificationVerificationStatus, the link to the original record in references.

\section{Datasets}

\section{Dataset description}

The Plant occurrences in Flanders and the Brussels Capital Region, is an export from www.waarnemingen.be. The data were standardized to Darwin Core using a SQL query. The included terms are: 
occurrenceID, type, language, license rightsHolder, accessRights, references, datasetID, institutionCode, datasetName, basisOfRecord, informationWithheld, dataGeneralizations, individualCount, sex, reproductiveCondition, establishmentMeans, samplingProtocol, eventDate, continent, countryCode, stateProvince, municipality, verbatimCoordinates, verbatimCoordinateSystem, verbatimSRS, decimalLatitude, decimalLongitude, geodeticDatum, coordinateUncertaintyInMeters, georeferenceRemarks, identificationVerificationStatus, taxonID, scientificName, kingdom, taxonRank, scientificNameAuthorship, vernacularName, nomenclaturalCode.

Generalized and/or withheld information: location information is generalized to $4 \times 4 \mathrm{~km}^{2}$ IFBL grid cells. Observer name, exact XY-coordinates, toponyms, and photographs are not included in the published dataset, but are stored in the source database. The dataset will be updated on GBIF on a regular basis (currently planned every two year).

Object name: Waarnemingen.be - Plant occurrences in Flanders and the Brussels Capital Region, Belgium

Format name: Darwin Core Archive format

Format version: 1.0

Character encoding: UTF-8

Language: English

License: http://creativecommons.org/publicdomain/zero/1.0/

Usage norms: http://www.natuurpunt.be/normen-voor-datagebruik

First publication date: $2016-12-23$

Distribution: http://dataset.inbo.be/planten-natuurpunt-occurrences

DOI: https://doi.org/10.15468/fyuklz

\section{Discussion}

Since 2010, the number of plant observations registered annually is larger than all the records available in www.waarnemingen. be before 2008. Observations are currently mainly presence only records (95\%). Presence is certain, absence of data can have multiple reasons: an IFBL grid cell was not visited, the species was not present/seen, the species was present but not registered in the database. For this reason, since the end of 2016, www. waarnemingen.be focusses more on lists and transect registration. During field work, the route can be tracked via the mobile app ObsMapp. At the end of the excursion, observers can indicate different types of lists, depending on whether: (1) the records are opportunistically collected presence only data (some records of some of the species encountered), (2) all individuals of selected species were registered, (3) all species were recorded or (4) all individuals of all species (more useful for animals than plants). This additional information allows to account for a better observation effort than currently is the case. 
The most frequently and widespread observed plant in www.waarnemingen.be is Urtica dioica. This species was in Van Landuyt et al. (2006) also the most widespread plant. The other plants on the top 10 of most frequently recorded plants shows there is bias in the data collected by the plant observers of waarnemingen.be. Species like Poa annua or Sagina procumbens should be seen much more than striking species like Cardamine pratensis, Filipendula ulmaria and Anemone nemorosa. This might be explained by the observers' lack of interest in very common species (Mair and Ruete 2016). Furthermore, spatial biases are expected since the data is collected opportunistically without mandatory sampling protocol (Geldmann et al. 2016). Sampling bias related to variation in recorder activity has been grouped in four main categories by Isaac et al. (2014): 1) uneven recording intensity over time, 2) uneven spatial coverage, 3) uneven sampling effort per visit and 4) uneven detectability. We aim to understand these biases better by stimulating the use of species lists rather than the collection of presence only data.

\section{Acknowledgements}

We thank the editor and reviewer for significant improvements to the manuscript. We thank all plant working groups and plant observers for their efforts to record plant observations all over Flanders and the Brussels Capital Region.

\section{References}

APG II (2003) An update of the Angiosperm Phylogeny Group classification for the orders and families of flowering plants: APG II. Botanical Journal of the Linnean Society 141: 399-436. https://doi.org/10.1046/j.1095-8339.2003.t01-1-00158.x

Geldmann J, Heilmann-Clausen J, Holm TE, Livinsky I, Markussen B, Olsen K, Rahbek C, Tøttrup AP (2016) What determines spatial bias in citizen science? Exploring four recording schemes with different proficiency requirements. Diversity and Distributions 22: 1139-1149. https://doi.org/10.1111/ddi.12477

Isaac N, van Strien AJ, August TA, de Zeeuw MP, Roy DB (2014). Statistics for citizen science: Extracting signals of change from noisy ecological data. Methods in Ecology and Evolution 5(10): 1052-1060. https://doi.org/10.1111/2041-210X.12254

Mair L, Ruete A (2016) Explaining spatial variation in the recording effort of citizen science data across multiple taxa. PLoS ONE 11(1): 1-13. https://doi.org/10.1371/journal.pone.0147796

Steeman R, Vervoort L, Lambrechts J (2012) Actualisatie Provinciale Prioritaire plantensoorten en aanzet voor de 'hotspotkaart van de bedreigde plantensoorten in Vlaams-Brabant'. Rapport Natuurpunt Studie 10: 1-51.

Van der Meijden R (2005) Heukels' Flora van Nederland, $23^{\text {th }}$ print, Wolters Noordhoff.

Van Landuyt W, Noé N (2015) Belgian IFBL Flora Checklists (1939-1971). Belgium Biodiversity Platform. Dataset/Occurrence. https://doi.org/10.15468/xnlbke 
Van Landuyt W, Brosens D (2017) Florabank1 - A grid-based database on vascular plant distribution in the northern part of Belgium (Flanders and the Brussels Capital region). Version 45.6. Research Institute for Nature and Forest (INBO). Dataset/Occurrence. http://www. gbif.org/dataset/271c444f-f8d8-4986-b748-e7367755c0c1

Van Landuyt W, Hoste I, Vanhecke L, Van den Bremt P, Vercruysse W, De Beer D (2006) Atlas van de Flora van Vlaanderen en het Brussels Gewest. Instituut voor Natuur- en Bosonderzoek: Brussel: Belgium.

Vriens L, Bosch H, De Knijf G, De Saeger S, Oosterlynck P, Guelinckx R, T'jollyn F, Van Hove M, Paelinckx D (2011) De Biologische Waarderingskaart. Biotopen en hun verspreiding in Vlaanderen en het Brussels Hoofdstedelijk Gewest, Mededelingen van het Instituut voor Natuur- en Bosonderzoek INBO.M.2011.1. Instituut voor Natuur- en Bosonderzoek, Brussel, 416.

Wieczorek J, Guo QG, Hijmans RJ (2004) The point-radius method for georeferencing locality descriptions and calculating associated uncertainty. International Journal of Geographical Information Science 18: 745-767. https://doi.org/10.1080/13658810412331280211 